\title{
界面インピーダンス法による水銀に対する 金属の濡栍評価
}

\author{
横田仁志 興戸正純 沖 猛雄
}

名古屋大学工学部材料機能工学科

J. Japan Inst. Metals, Vol. 57, No. 12 (1993), pp. 1445-1450

\author{
Estimation of Wettability between Metals and $\mathrm{Hg}$ by Interfacial Impedance Method \\ Hitoshi Yokota, Masazumi Okido and Takeo Oki \\ Department of Materials Science \& Engineering, Faculty of Engineering, Nagoya University, Nagoya
}

\begin{abstract}
The interfacial impedance method is widely applied for the analysis of interfacial electrochemical phenomena. In this paper, the wettability of some metals to mercury was measured by means of the interfacial impedance method. The variations of impedance response for metal/mercury/metal with time were measured after dipping a pair of metal electrodes into the liquid mercury. $\mathrm{Pb}, \mathrm{Zn}, \mathrm{Cu}, \mathrm{Ni}$ and $\mathrm{Fe}$ wet to mercury in the order of their wettability magnitude. The equivalent circuit at the interface between mercury and metals is considered to be a parallel circuit of resistance, $R_{\mathrm{r}}$, and capacitance, $C_{\mathrm{dl}}$, from the measurement of frequency response. The improvement of wettability with time leads to the increase of $C_{\mathrm{al}}$ and the decrease of $R_{\mathrm{r}}$. The impedance parameter is affected by the surface roughness of the metals. The interfacial wettability can be evaluated by means of the interfacial impedance method which has a small observation error in comparison with the measurement of sessile drop.
\end{abstract}

$$
\text { (Received July 1, 1993) }
$$
Keywords: impedance, wettability, interfacial impedance method, mercury, sessile drop, interfacial
double layer capacitance

\section{I. 緒䓂}

濡れ性の評価法は種々考案されている。固体/液体界面の接 触角を測定する方法もその一つであり，静滴法(1)，傾斜板法， 垂直板法，粉末法等(2)がある、いずれも断面形状等を測定し， 計算によって接触角を求める方法である。ぬた，万ら付性も濡 れ性と関連があるとされ, 広がり試験法, 漫透試験法, 浸漬試 験法が考案実施されている(3)。これらは濡れ性を面積や長さと 関連付付て測定する方法である。

一方界面インピーダンス法は界面反応機構解明へのアプロー チの重要な手段の一つとして広く応用されている。一般に電気 化学系の界面では接触する二相内部の共通する金属イオンの内 部ポテンシャル差により界面には電気二重層が形成される、イ ンピーダンス測定によりこの二重層容量を見積るることが可能 なことが知られている，同様の観点から異種金属間界面でも電 子の内部ポテンシャル差よりこれと同様の容量が存在すると考 えられる．金属/金属間の濡れ性がこの容量と何らかの関係が 两ると思方孔るため，水銀と他の固体金属間の界面インピーダ ンス測定を行い界面インピーダンス法による濡孔性評価の基礎 研究を行った。

$† 1989$ 年 5 月日本軽金属学会に扣いて発表
III 実験装置および方法

\section{1. 実験装置}

実験用セルにはFig. 1(a)，(b)に示す2種類のものを用い
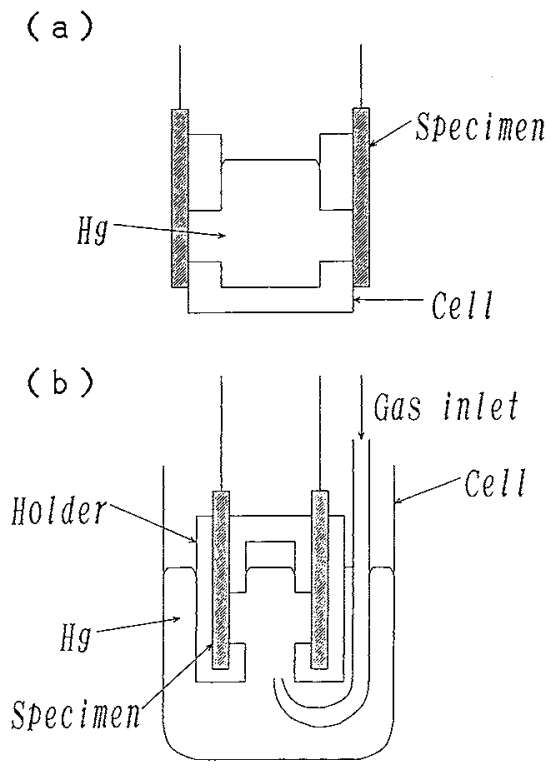

Fig. 1 Experimental cell (a) standard, (b) for gas blowing. 
た、（a）は水銀静止測定用であり(b)は水銀脱がス測定用であ る.（a）のセルは $5 \mathrm{~mm}$ 厚の塩化ビ =ール板を直方体状に接着 して作成した．直径 $10 \mathrm{~mm}$ ののあいた相向かい合ら二面 (面間距離 $40 \mathrm{~mm}$ ) 飞試料金属板をエポキシ系接着剂で貼付け， セルの中に水銀を入え試料金属/水銀/試料金属からなる系を作 成した（b)は試料金属板を塩化ビニール製のホルダーに固定 しホルダーごとビーカーの中に入れ，そこへ水銀を満たすよう にした。 また，ガラス管を通してアルゴンガスを吹込み，液体 水銀内の溶存がスを除いたそそれぞれ，二枚の試料金属板には リード線を接続して，試料金属/水鍟/試料金属からなる系のイ ンピーダンス応答を測定した。

供試材には純度 99.9 mass\%の鉄，ニッケル，銅，亜鉛，鉛 の $1 \mathrm{~mm}$ 厚の压延材を用いた.アマルガムの形成の難易性は, 覀鉛，鉛，銅，二ッケル，鉄の順で，鉄は実用上合金形成が無 いとされている(4).この反応性の違いは需れ性と関連があり需 れ性の違いを比較するためにこれらの金属を選んだ、試料金属 板は $12.5 \mathrm{~mm} \times 25 \mathrm{~mm}$ の大ささとた。.試料金属表面をアセ トン洗浄しただけのものとバフ研磨後アセトン洗浄したものを 用いた、なお、リード線との接続はクリップを用い接触抵抗が $10^{-7} \Omega \mathrm{m}^{2}$ 以下になるよらに心掛けた。

本銀は空気酸化による連続洗浄装置と洗浄塔によって精製し たもの，专るいは精製後アルゴンガスによる脱気を行ったもの を用いた。

\section{2. 測定方法}

界面インピーダンス応答測定回路をFig. 2 亿示す。測定 に柱周波数応答解析装置 (FRA: Frequency Response Analyzer；エヌェフ回路設計ブロック製S-5720)を用いた。

交流信号を試料金属対と $1 \Omega$ 標準抵抗を直列接続した間に 加兄た、標準抵抗の両端の電圧，試料間の電圧と交流信号周波 数よりインピーダンスの周波数分散が FRA 内で求められる. インピーダンス $Z(=R+j X)$ は複素平面 $(R,-X)$ 上にプロッ

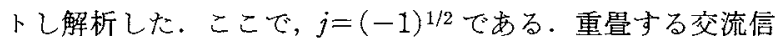
号振幅は $1 \mathrm{~V}$ ，交流信号周波数範囲は $2 \mathrm{MHz}$ から $10 \mathrm{~Hz}$ ，測 定点はディケード当り10点とした１スウィープの測定に約 180 sを要した。インピーダンスは連続測定とし，水銀が各金 属と接触した後のインピーダンスの経時变化を測定した。 た, インピーダンスの時間变化の著しいものは単一周波数で测 定を行った。

\section{3. 接触角測定}

界面インピーダンス法による濡れ性の評価を他の定量的濡れ

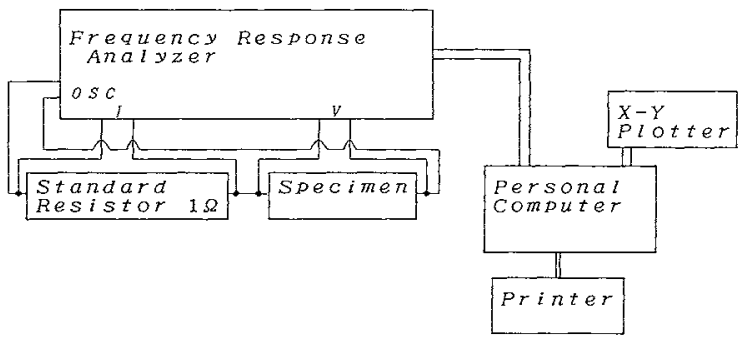

Fig. 2 Experimental apparatus for impedance measurement.
性評価と比較するため，静滴法による接触角の経時变化を測定 した．試料金属を水平に置いて上部から注射器で水銀約 $1 \mathrm{~cm}^{3}$ を滴下し側面より水銀形状を写真撮影した。鉄，ニッケルでは 約 $21.6 \mathrm{ks}$ ，銅では約 $10.8 \mathrm{ks}$ ，亜鉛，鉛では約 $3.6 \mathrm{ks}$ にわた って接触角が一定になるまで形状変化を観察した。

雾团気恔アルゴン雾团気とした。試料金属はインピーダンス 測定と同様の材料を用いた。実験は室温で行った。

\section{III. 実験結果および考察}

\section{1. $\mathrm{Fe}, \mathrm{Zn}$ 試料のインピーダンス特性}

Fig. 3(a)-(f)飞水銀と濡れ性の悪い鉄と濡れ性の良い亜鉛 のインピーダンス軌跡の例を示す，各測定点における周波数を 図中に示した。

鉄, 亜鉛どちらの場合でも $10 \mathrm{kHz}$ 以上という高周波域の軌 跡が現れた。水溶液系でのインピーダンス測定の場合では 10 $\mathrm{kHz}$ 以下の周波数域で軌跡が描かれる昜合が多い

本実験のように被測定系のインピーダンスのオーダーが小さ い場合，測定《使用するリード楾の影響を無視することはでき ない、したがって，水銀を含まないりード線と試料極のみのイ ンピーダンス応答を測定することにより補正を行った。

すなわち，(a)，(d)がそれぞれ鉄，巠鉛に対するすべての測 定系の応答であり，(b)，(e)は水銀を含まないリード線之試料 整のみの補正部分の応答である。(a)から(b)を減算したるの を(c)に，(d)から(e)を減算したものを(f)飞示す。したがっ て，(c) 委たは(f)は試料金属/求銀界面部分之水銀部分からな る系の応答になるものと考劣られる。

(b)の鉄と(e)の無鉛で軌跡の形状に大きな差はない、いず (a)

(b)
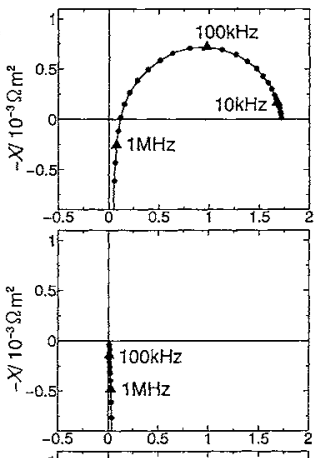

(c)

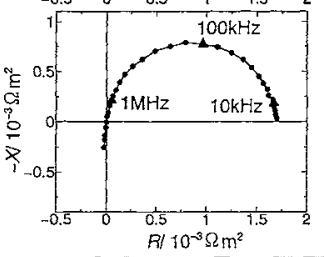

(g)

(h)

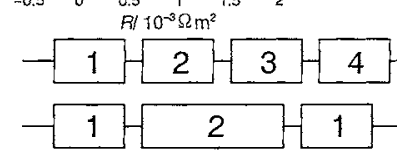

(d)

(e)

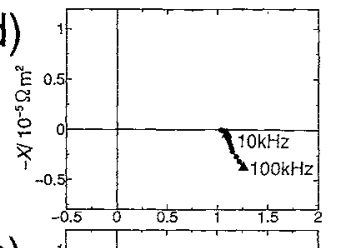

(f)

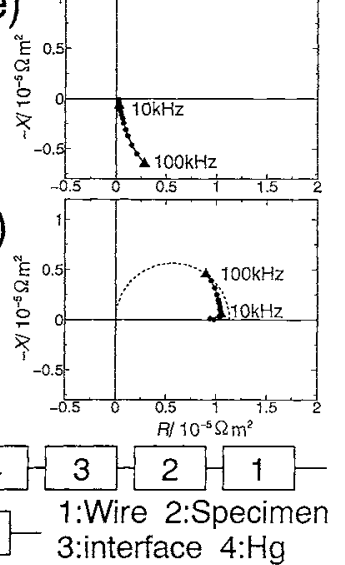

Fig. 3 Typical impedance plots, (a) overall impedance for $\mathrm{Fe} / \mathrm{Hg}$, (b) impedance for $\mathrm{Fe}$ without $\mathrm{Hg}$, (c) compensated by (a)-(b), (d) overall impedance for $\mathrm{Zn} / \mathrm{Hg}$, (e) impedance for $\mathrm{Zn}$ without $\mathrm{Hg}$, (f) compensated by (d)-(e), (g) schematic of overall impedance, (h) schematic of impedance without $\mathrm{Hg}$. 
れも複素平面上で第四象限に軌跡が得られた。補正する前の (a)の鉄では第一象限の軌跡が，（d）の亜鉛は第四象限の軌跡 が観察されるが，それぞれ(b) または(e)を減算することによ り (c), (f)のような容量性の軌跡となった.

(c)の鉄の場合, 原点を通って中心が実軸上にある半円軌跡 を呈した.（f）の亜鉛では鉄と比較して全測定系のインピーダ ンスと補正すべきインピーダンスの值の差が小さかった。 た，実数軸付近の低周波数域の軌跡形状が半円からずれ歪んで いた. 形状が歪む理由は測定中に界面で何らかの反応が生じて 等価回路が変化するためではないかと思われる.

(a)-(f) で測定されたインピーダンスについて，測定值を模 式的に示すとFig. 3(g)，(h)のようになる.（g)は(a)，(d)に， (h)は (b)，(e)に相当する.（g)は全測定系のインピーダンスで あり, 周波数応答解析装置とセルとを結ぶリード線, 試料金 属, 水銀とそれぞれの界面をすべて含む応答であると考学られ る.

(c), (f)のインピーダンス軌跡が一つの容量性の半円を呈す ることから界面の等価回路は容量成分と抵抗成分の並列回路で あると考えられる. 容量成分を $C_{\mathrm{dl}}$, 抵抗成分を $R_{\mathrm{r}}$ と括くと インピーダンスの複素表示 $(R,-X)$ は, 次式の円の式で表さ れる.

$$
\left(R-R_{\mathrm{r}} / 2\right)^{2}+X^{2}=\left(R_{\mathrm{r}} / 2\right)^{2}
$$

半円頂点角周波数 $\omega_{0}$ と半円直径 $R_{\mathrm{r}}$ から $C_{\mathrm{dl}}$ が次式により求め られる.

$$
C_{\mathrm{dl}}=1 /\left(\omega_{0} R_{\mathrm{r}}\right)
$$

ただし， $\omega_{0}=2 \pi f_{0}\left(f_{0}\right.$ : 半円頂点周波数, 単位 $\left.\mathrm{s}^{-1}\right)$ である.

Fig. 3 より各インピーダンスパラメータを求めると亜鉛では $R_{\mathrm{r}}=1.1 \times 10^{-5} \Omega^{2}, C_{\mathrm{dl}}=7.2 \times 10^{-2} \mathrm{Fm}^{-2}$, 鉄では $R_{\mathrm{r}}=1.7 \times$
$10^{-3} \Omega \mathrm{m}^{2}, C_{\mathrm{dl}}=7.9 \times 10^{-2} \mathrm{Fm}^{-2}$ となった．濡れやすい亜鉛で は $R_{\mathrm{r}}$ は小さく $C_{\mathrm{dl}}$ は大きくなった. ここで $C_{\mathrm{dl}}$ は水銀/金属間 の二重層容量に相当し， $R_{\mathrm{r}}$ は電荷移動の界面抵抗に相当する ものと考兄られる．また，測定されたFig. 3(c)，(f) には水銀 の抵抗も含まれているが，その值は無視できるほど小さいと推 察される．このような結果から，固体金属と液体金属の界面で の濡れ性を界面インピーダンス法により測定評価するとき，イ ンピーダンスパラメータである $C_{\mathrm{dl}}$ あるいは $R_{\mathrm{r}}$ の值を求める ことが重要と思われる.

鉄, 亜鉛以外の金属の場合でも同様の高周波領域の半円もし くは半円の一部の軌跡が得られた. インピーダンスプロットの 時間変化については傾向は二種類であった. すなわち, 半円の 軌跡の半径が時間とともにほとんど変化しない場合と半径の大 きさが変化する場合である. 変化の程度は金属により異なり, 同種金属でも実験時の界面の違いにより応答が異なっていた。

\section{2. 各種金属のインピーダンス応答}

頂点角周波数 $\omega_{0}$ の逆数は時定数と言われ $\tau_{0}$ (単位は $\mathrm{s}$ ) で表 される.この值は界面の緩和現象を反映しているものと考光ら れる. 金属と水銀との界面に猢るる需孔現象の場合に頂点周波 数は $10 \mathrm{kHz}$ 以上であることから，その界面緩和はかなり速い ものと思われる.

時間変化の著しいインピーダンスを測定するために単一周波 数 $(100 \mathrm{kHz})$ で測定を行った場合の各インピーダンスパラメー タの計算は以下の式を用いた.

軌跡の式が式 (1)で表される場合, 半円上の一点の座標を $\left(R_{1}\left(\omega_{1}\right),-X_{1}\left(\omega_{1}\right)\right)$ とすると, 等価回路の容量成分 $C_{\mathrm{dl}}$ と抵抗 成分 $R_{\mathrm{r}}$ はそれぞれ次式のように書き表される.
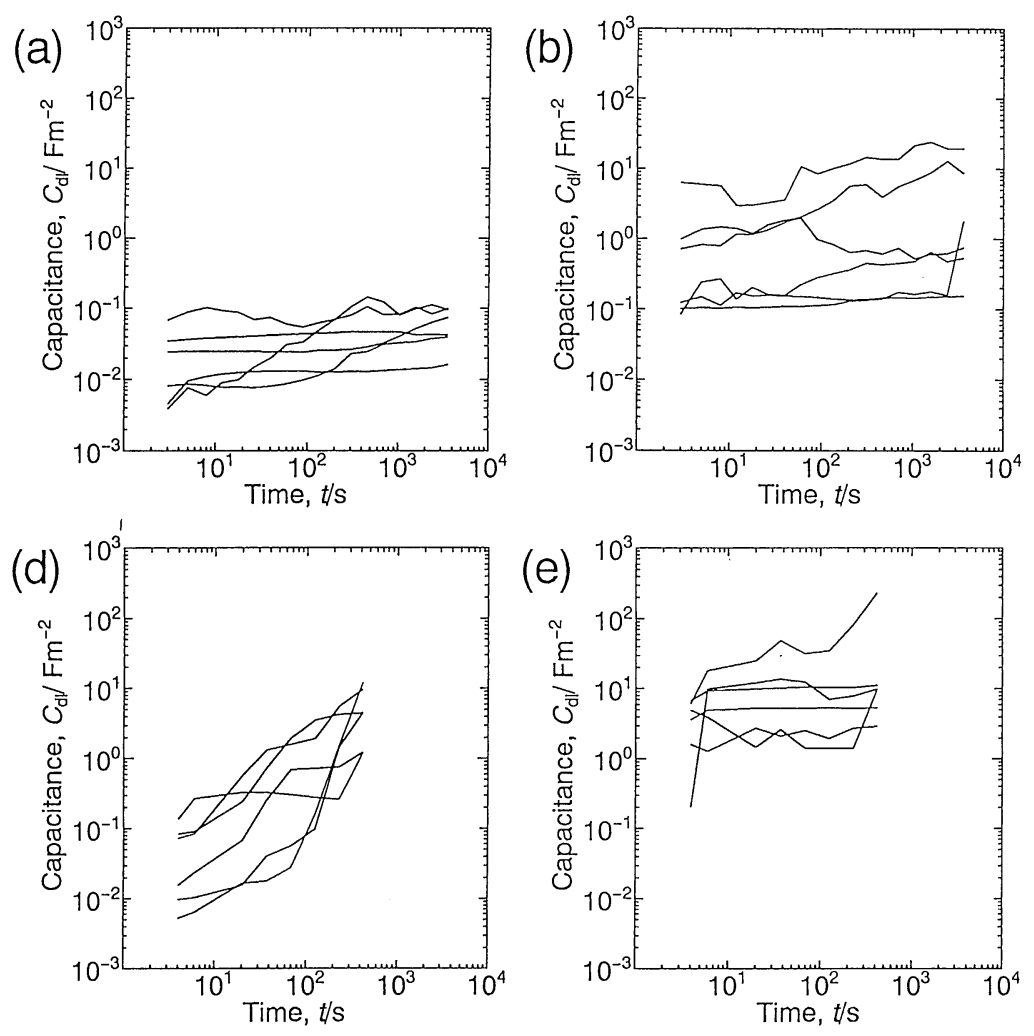

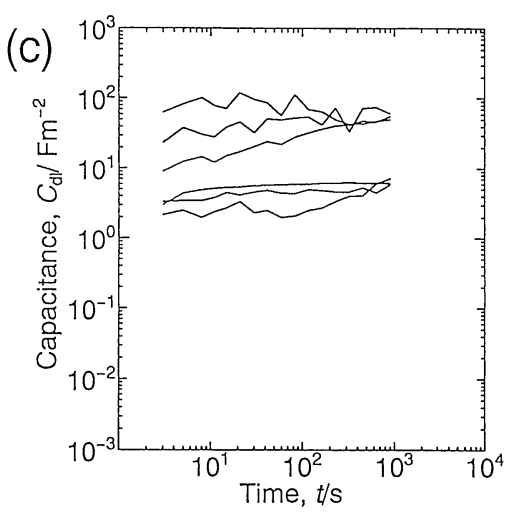

Fig. 4 Variation of $C_{\mathrm{dl}}$ at $\mathrm{Fe} / \mathrm{Hg}$ interface (a), $\mathrm{Ni} / \mathrm{Hg}$ interface (b), $\mathrm{Cu} / \mathrm{Hg}$ interface (c), $\mathrm{Zn} / \mathrm{Hg}$ interface (d) and $\mathrm{Pb} / \mathrm{Hg}$ interface (e) with time using $\mathrm{Hg}$ without degassing and the polished specimen. 
(a)
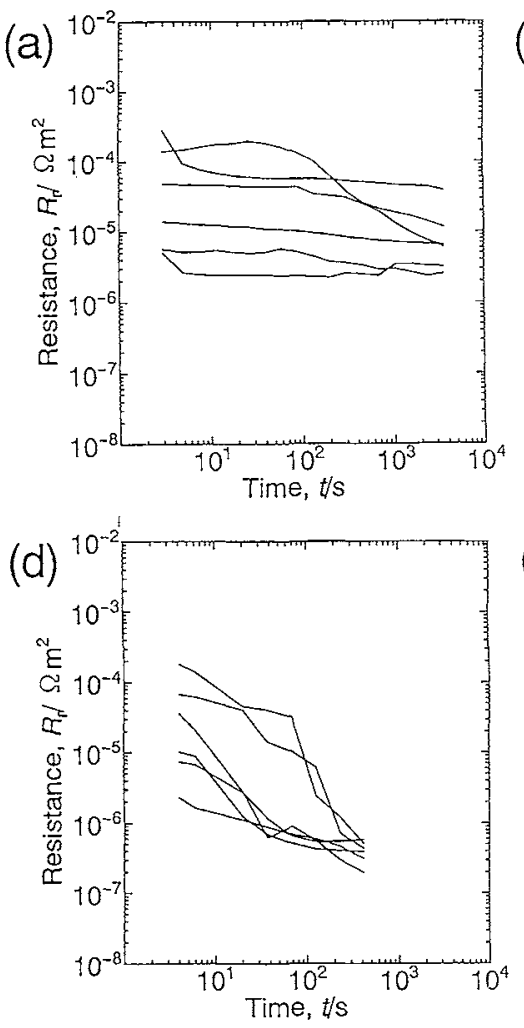

$$
C_{\mathrm{dI}}=-X_{1}\left(\omega_{1}\right) / \omega_{1} \cdot\left[\left\{R_{1}\left(\omega_{1}\right)\right\}^{2}+\left\{X_{1}\left(\omega_{1}\right)\right\}^{2}\right]
$$$$
R_{\mathrm{r}}=\left[\left\{R_{1}\left(\omega_{1}\right)\right\}^{2}+\left\{X_{1}\left(\omega_{1}\right)\right\}^{2}\right] / R_{1}\left(\omega_{1}\right)
$$
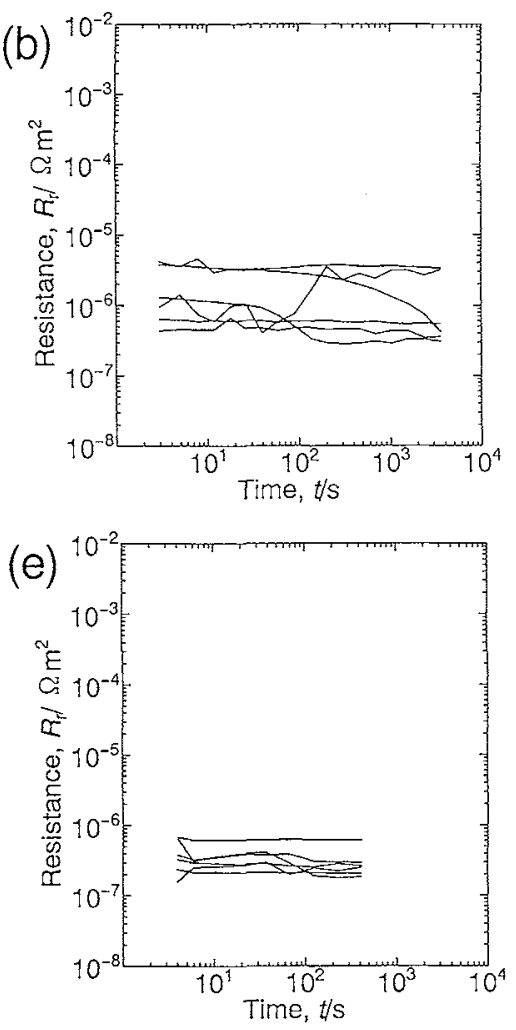

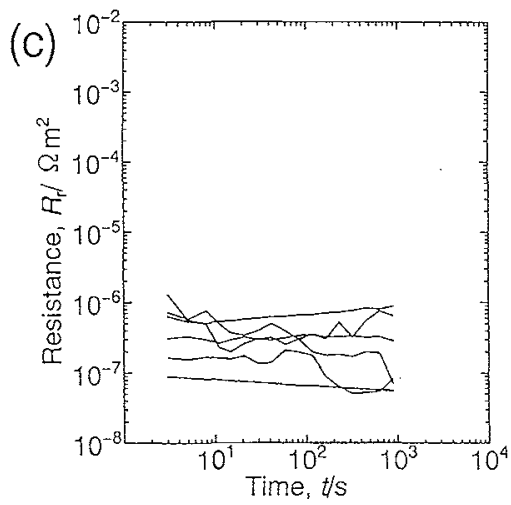

Fig. 5 Variation of $R_{\mathrm{r}}$ at $\mathrm{Fe} / \mathrm{Hg}$ interface (a), $\mathrm{Ni} / \mathrm{Hg}$ interface (b), $\mathrm{Cu} / \mathrm{Hg}$ interface (c), $\mathrm{Zn} / \mathrm{Hg}$ interface (d) and $\mathrm{Pb} / \mathrm{Hg}$ interface (e) with time using $\mathrm{Hg}$ without degassing and the polished specimen.
これらの式を用いて各金属と水銀界面のインピーダンスパラタ 一タの経時変化を測定した。

脱気を施していない水銀を用い，試料表面の機械的研磨を行 った場合の容量成分 $C_{\mathrm{dI}}$ の経時変化を Fig. 4 K，抵抗成分 $R_{\mathrm{r}}$ の経時変化をFig. 5 K示す. 各グラフ中のいくつかのライン は数回の実験による違いで西り，それらには大きな゙ラッキが 見られた。

Fig. 4, Fig. 5 に括いて亜鉛の場合は時間によりそれぞれ大 きく変化するが，その他の金属の場合は経時変化は压とんど無 い。た $R_{\mathrm{r}}$ の平均は鉄, ニッケルと比較して亜鉛，鉛は小さ い值であり逆に $C_{\mathrm{dl}}$ の平均は後者が大きい值をとっている。ま た経時変化は $C_{\mathrm{dl}}$ が増加傾向であり $R_{\mathrm{r}}$ は減少傾向であった。 湘定終了後各金属表面を観察したところ，亜鉛では水銀と合金 化し亜鉛中に深く入り达んでいた。鉛では表面全体に水銀が付 着していた．銅では少量の水銀が表面に付着していた．鉄，二 ッケルでは水銀が付着はなかった。

数回の測定を繰り返した各測定において $C_{\mathrm{d} 1}, R_{\mathrm{r}}$ の値は広い 範围にバラッキを持つ.これは前処理を同様にする上5に心が けたが，金属表面状態や酸化皮膜の生成など必ずしも同様な表 面性状になっていないことによると考觉られる．更に，水銀中 の不純物やガスの影響もあるすのと思われる，そこで，次に表 面研磨の効果と水銀の脱気の効果について検討を行った.

\section{3. 表面研磨之脱気の効果}

アルゴンガスのバブリングにより脱気した承銀を用い，試料 表面の機械的研磨を行った場合の容量成分 $C_{\mathrm{dl}}$ の経時变化を
Fig. 6 亿示す.

脱気した乐銀を用いると脱気しない場合と比較して容量成分 の值は増加した。これは水銀中の溶存酸素がアルゴンガスのバ ブリングにより除去され，鉄や亜鉛の酸化が抑制されたり，陚 料表面の吸着酸素等が減少したためと考光られる。

また，脱気していない水銀を用い表面の機械的研磨を施して いない場合の容量成分 $C_{\ddot{a 1}}$ の経時変化を Fig. 7 亿示す。表面 を研磨したFig. 4 の $C_{\mathrm{dl}}$ と比較すると，研磨していないFig. $7 の C_{\mathrm{dI}}$ は小さくなった。一般に濡れ性は試料表面の平滑性に 影響される。接触角に対する粗度の影響が無視されるためには 面の傾きが 1 度以内, 凹凸の深さ $10^{-1} \mu \mathrm{m}$ (この平滑度は工業 的研磨の限界に近いであれ独いとされている(2)。研磨を行 らと表面の酸化膜などが取り除かれ水銀が接触しやすくなるた め，容量成分の值が大きくなると考光られる，容量は $\mathrm{Fm}^{-2}$ の次元を有するため，水銀との有效な接触面積の増加は $C_{\mathrm{al}}$ を 増加させる、西るいは次の上らにも考觉られる。すなるち, 容

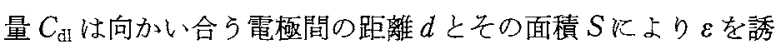
電率として $C_{\mathrm{dl}}=\varepsilon \cdot S / d$ と一般に表される. 酸化皮膜が存在し 水銀と鉄または亚鉛が十分濡孔ない場合には， $d$ が存在し $C_{\mathrm{dI}}$ は小さくなる。このような 2 つ理由により，溶存酸素があ る場合に $C_{\mathrm{d} 1}$ は小さくなると推察される.

鉛，亜鉛などの水銀纪付着し易い金属がある時間経過したと き炡宗量成分 $C_{\mathrm{dl}}$ の值は $10^{2} \mathrm{Fm}^{-2}$ 程度, 抵抗成分 $R_{\mathrm{r}}$ の 值は $10^{-7} \Omega \mathrm{m}^{2}$ 程度になる.すなわ占，水銀/金属系の濡れ現 象において界面インピーダンス法を用いて濡れ性を評洒する場 合, 需れた状態とは容量成分と抵抗成分の値がこの程度のオー ダーになったときと言える。 
(a)

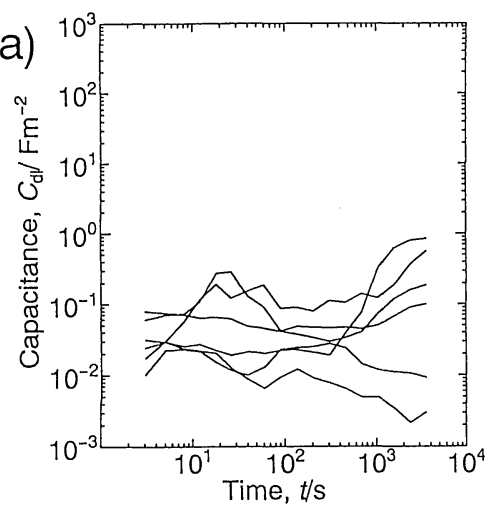

(d)

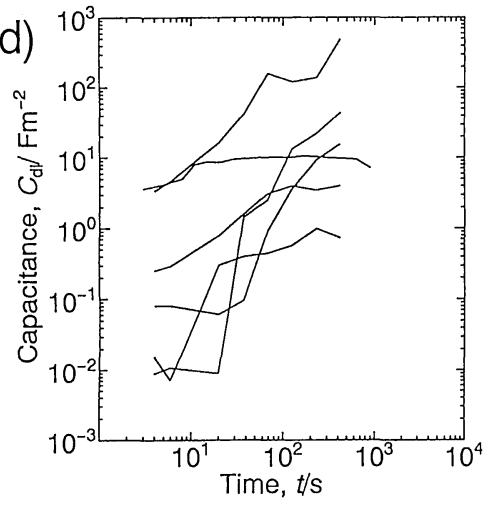

(a)
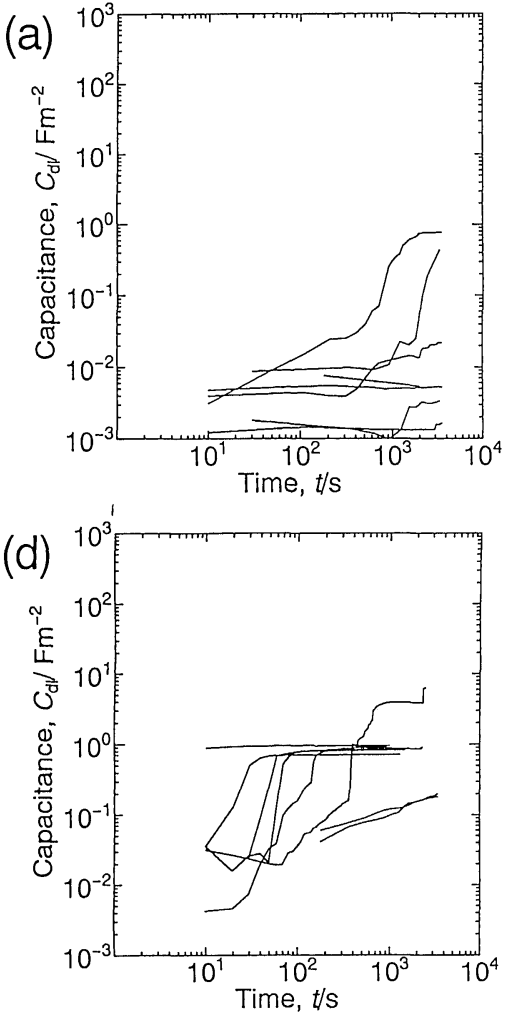

(b)

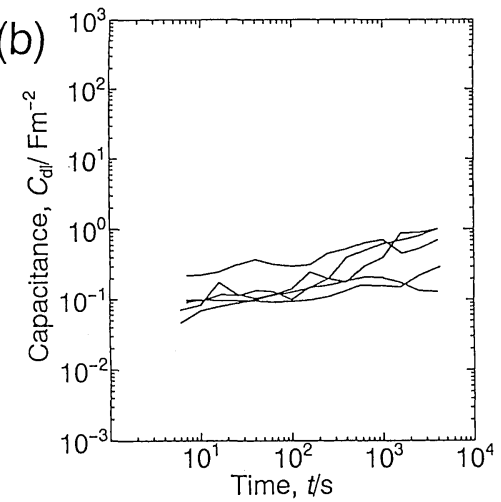

(e)

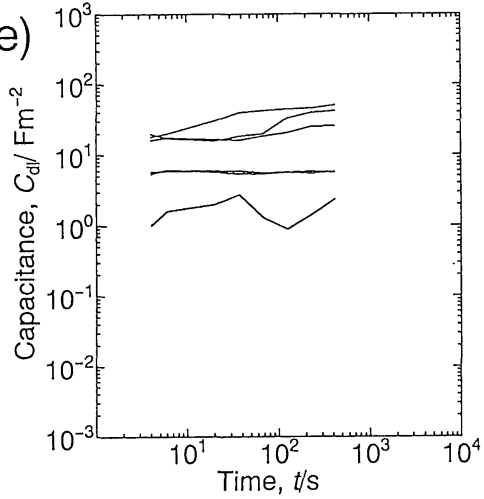

(c)

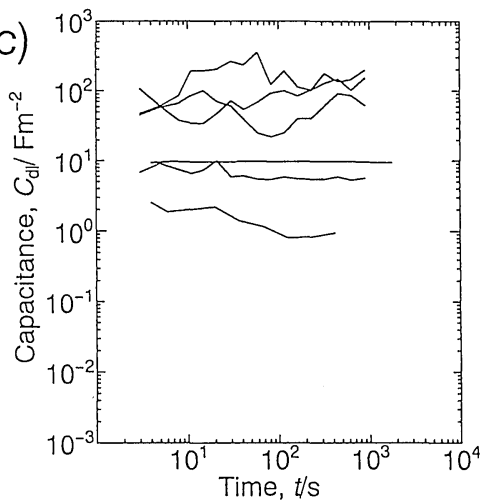

Fig. 6 Variation of $C_{\mathrm{dl}}$ at $\mathrm{Fe} / \mathrm{Hg}$ interface (a), Ni/Hg interface (b), $\mathrm{Cu} / \mathrm{Hg}$ interface (c), $\mathrm{Zn} / \mathrm{Hg}$ interface (d) and $\mathrm{Pb} / \mathrm{Hg}$ interface (e) with time using $\mathrm{Hg}$ with degassing and the polished specimen.
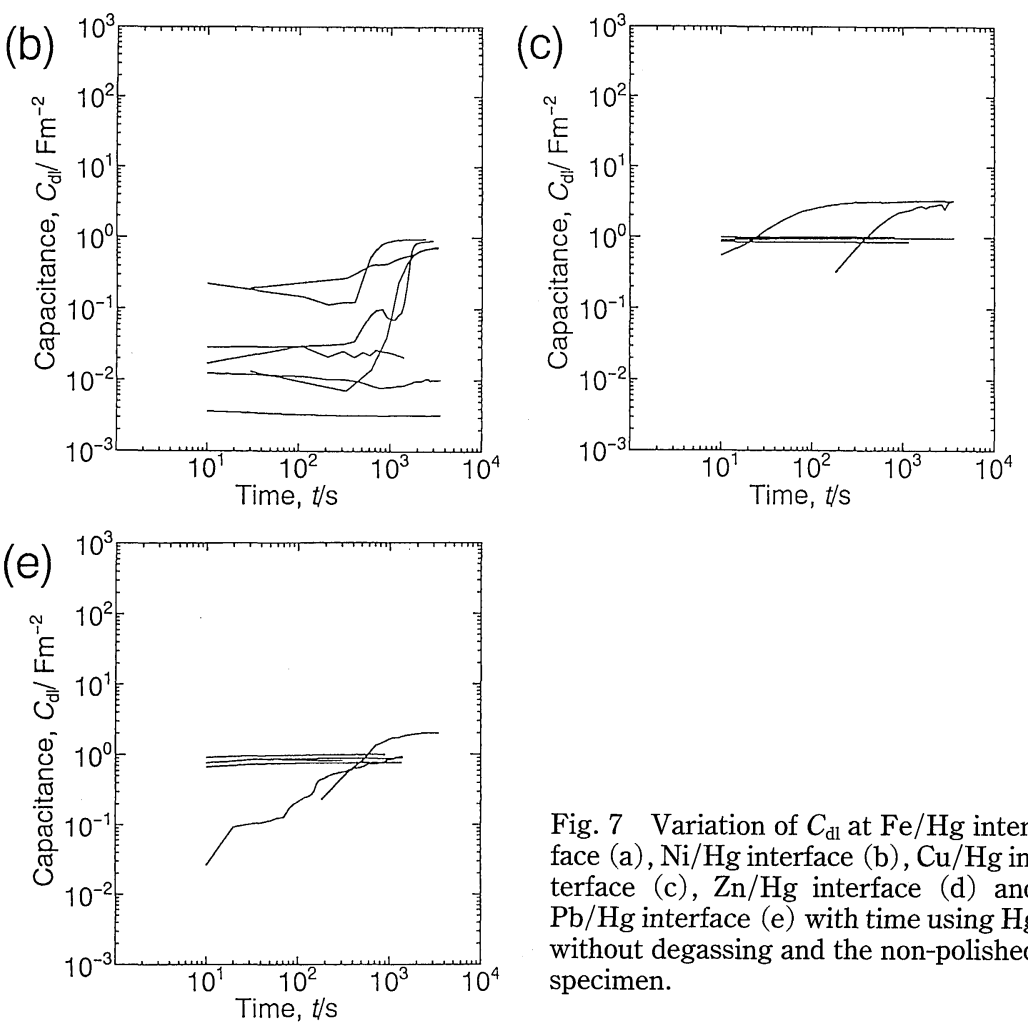

Fig. 7 Variation of $C_{\mathrm{dl}}$ at $\mathrm{Fe} / \mathrm{Hg}$ interface (a), $\mathrm{Ni} / \mathrm{Hg}$ interface (b), $\mathrm{Cu} / \mathrm{Hg}$ interface (c), $\mathrm{Zn} / \mathrm{Hg}$ interface (d) and $\mathrm{Pb} / \mathrm{Hg}$ interface (e) with time using $\mathrm{Hg}$ without degassing and the non-polished specimen.

\section{4. 接触角との比較}

接触角の経時変化を Fig. 8 に示す。（a）は精製しただけの水 銀を用いた場合，(b)は更に脱気を行った水銀を用いた場合で ある. 鉄, ニッケルでは時間による変化はほとんど見られず,
銅，亜鉛，鉛では時間とともに接触角が減少する傾向を示し た．特に鉛では減少傾向が顕著であった．

水銀中にアルゴンガスを吹き込んで脱気した効果が接触角の 変化においても認められる. Fig. 8(a)と(b)を比較すると, 脱 気を行った $(b)$ の方が接触角は小さくなっている．特に水銀に 


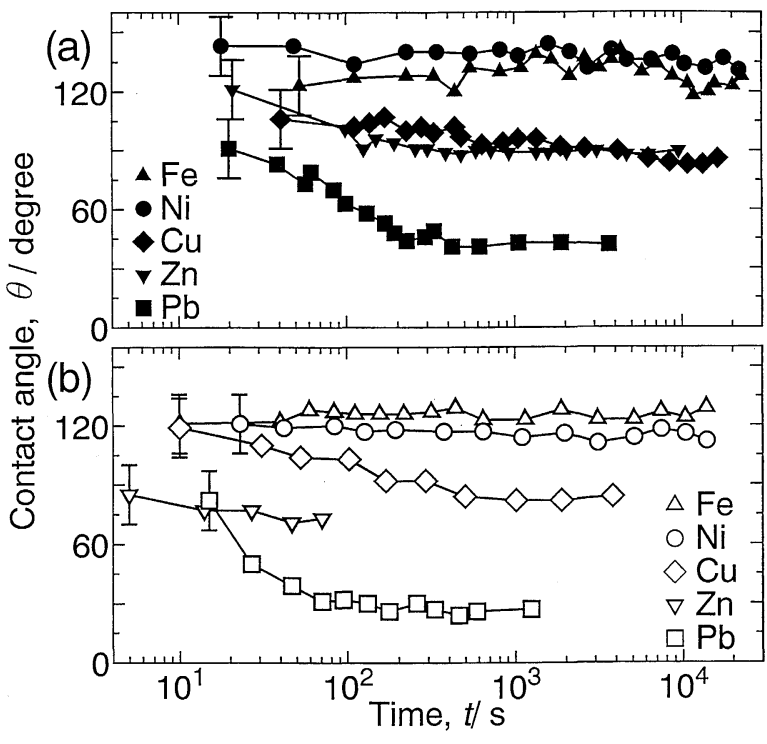

Fig. 8 Variation of contact angle with time using $\mathrm{Hg}$ without degassing (a) and with degassing (b).

付着し易い亜鉛や鉛ではこの減少量は大きい。

各金属ごとに界面インピーダンス法による容量成分の経時変 化と接触角の経時変化を比較すると両者は必ずしも一致してい ない，例えば鉛の場合，界面インピーダンス応答では Fig. 4 に示したように容量成分の経時変化はほとんど無いが，接触角 の減少傾向は大きい。また亜鉛の場合，時間による容量成分の 増加傾向は大きいが，接触角の変化は少ない。

しかし，各金属ごとではなく全体の傾向を考㝋てみると，界 面インピーダンス法で求めた容量成分の変化と接触角の変化に は大まかな相関が見られる，すなわち，接触角が大きいるのは 容量成分は小さく, 接触角の経時変化が減少する傾向にあるも のは容量成分は時間に対して増加する傾向を示している.

また，接触角の経時変化測定中に各金属と水銀の接触状態を 肉眼で観察したところ，その形態は各金属で異なっていた。す なわち, 鉄, ニッケルを $86.4 \mathrm{ks}$ 以上水銀と接触させても水銀 の付着は見られなかったが，銅では $600 \mathrm{~s}$ ほどで水銀が銅表面 に付着した. 一方, 亜鉛では水銀滴接触後数秒で覀鉛表面に水 銀が付着し，水銀滴の形状がほとんど変わらないままに水銀中 に亜鉛が溶解し始め約 $900 \mathrm{~s}$ で带鉛板に貫通孔が開いた．更に 鉛では, 水銀滴接触後ただちに水銀が鉛表面に付着しそのまま 表面に沿って全体に拡張していったが，亜鉛の場合と異なり孔 が開くようなことはなかった.

接触角と界面インピーダンス応答との対応を，このような水 銀との接触状態を併せて考えると以下のよらになる.すなわ ち，亜鉛の場合接触角はわずかな減少変化であったが，水銀と 亜鉛が接触している部分での溶解の進行は激しかった．このよ らな現象はインピーダンスパラメータでは容量成分の増加傾向 に対応しているるのと考えられる。一方，鉄やニッケルの場合 では接触角の経時変化はほとんど無く，その接触部分での水銀 の付着も観察されなかった. この時容量成分の経時変化もほと んど無く，しかもその值は鉛や亜鉛と比較すると小さい值であ った．また，容量成分の值が大きく，経時変化がほとんど無か
った鉛の場合では，接触角の減少変化は顕著であった．しか し，この場合の濡れ現象は付着濡れではなく，拡張濡れであっ た．以上のことょり，容量成分の大小は水銀の付着濡れの有無 に対応しているように思われる。

接触角とインピーダンスパラメータの対応は以上のように考 えられるが, “界面インピーダンス法では二相の接触界面部分で の現象を反映した応答を測定している．接触角の測定とは異な ったアプローチによる濡れ現象の評価が可能と思われる.

\section{5. 他の濡れ性の測定法との比較}

従来の濡孔性の評価法では, 液体金属相, 固体金属相, 気相 の三相の交点において表面エネルギーを減ずるように液体金属 が移動し固体/液体間の面の拡張あるいは収縮が生じることを 基本に和いて括り，固体/液体の接触する全界面の情報に欠け 重力の影響もある. それに対し，濡れ性評価法としての界面イ ンピーダンス法には次のような特徵がある. まず第一に固体/ 液体界面全体の電気的応答を測定することである．第二に濡れ 性の生じている界面の測定に雾囲気の影響を受けにくいことで ある. 固体表面に液滴を載せてその接触角を測定する方法では 周りの気体雾囲気の影響を受け，その影響を除くように雾囲気 を一定にすることは容易ではない，第三に時間変化の測定が容 易であり, 測定誤差は測定装置の精度によって定まり測定誤差 の小さい界面の情報が得られる. 第四に交流電流が流れない系 では，測定できない問題があるが，高周波数を用いることによ って絶縁体に近い材料へ応用も可能になると期待される.

\section{N. 結 論}

固体金属 (鉄, ニッケル, 銅, 亜鉛, 鉛) と液体水銀間の濡れ 性を界面インピーダンスから評価する新しい方法を試み，次の 結果を得た。

（1）固体金属/水銀間の界面の電気的な等価回路は抵抗成分 と容量成分の並列回路で表される.

（2）水銀/金属系の濡孔が良い状態では界面の容量成分の值 は $10^{2} \mathrm{Fm}^{-2}$ 程度, 抵抗成分の值は $10^{-7} \Omega \mathrm{m}^{2}$ 程度であった。 濡れの悪い状態では容量成分の值は小さくなり, 抵抗成分の值 は大きくなった。

（3）金属表面機械的研磨の有無，水銀の脱気有無により濡れ 性は変化し, 測定される界面インピーダンスパラメータ $\left(C_{\mathrm{d}}\right.$, $R_{\mathrm{r}}$ ) 対応して変化した.

（4）静滴法による評価と対応がとれた，すなわち，接触角が 小さい場合, 容量成分 $C_{\mathrm{dl}}$ は大きくなった. インピーダンス法 は界面の濡れ性評価が可能であり, 界面全体の応答を求められ る点に特徵がある.

\section{文献}

(1) F. Bashforth and S. C. Adams: An Attempt to Test the Theories of Capillarity, Cambridge Univ. Press, (1883).

（2）日本化学会編：新実験化学講座18界面とコロイド，丸 善, (1977).

(3) 大森 明：溶接学会誌, 47(1978), 192.

（4）西川精一: 金属工学入門第而編非鉄金属材料乞の他, ア グネ技術センター，(1985)。 